\title{
Perancangan Aplikasi Pengajuan Reward atas Publikasi Ilmiah dan Hki di Universitas Terbuka Berbasis Website
}

\author{
Erman arif $^{\# 1}$, Dedy juniadi ${ }^{* 2}$, Yosi mardoni ${ }^{\# 3}$

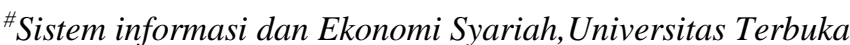 \\ Jalan Cabe Raya, Pondok Cabe, Pamulang, Tangerang Selatan 15437, Banten - Indonesia \\ ${ }^{1}$ erman.arif@ecampus.ut.ac.id \\ ${ }^{3}$ yosimardonidecampus.ut.ac.id \\ 2dedy.juniadieecampus.ut.ac.id
}

\begin{abstract}
Lecturers are now expected to become experts in the field of scientific studies from the research process then conveyed to students through teaching and besides being distributed to the community through community service, the outputs of research and service activities are Books, Articles, IPRs, applications and others. In accordance with the rules of the Open University Chancellor Number: 162 of 2019 concerning awards for publication works and Intellectual Property Rights within the Universitas Terbuka environment, the letter explains that each lecturer is entitled to receive an award for each publication that has been made, It's just that currently the awarding process is still using manual methods, lecturers fill out the forms provided by the faculty. Based on the slow process, the research team considers that Universitas Terbuka needs to develop a website based application in order to become an information system for lecturers to update the process of pro-posing awards for publication works and Intellectual Property Rights within the Universitas Terbuka. The study uses a two year assignment and multi year scheme. The outputs of this assignment research are articles, IPRs, and application prototypes.
\end{abstract}

Keywords- e-reward; management information systems; Website Application

Abstract - Dosen saat ini diharapkan menjadi pakar dalam bidang kajian ilmunya melalui proses penelitian, kemudian disampaikan ke mahasiswa melalui pengajaran, dan selain itu dibagikan ke masyarakat lewat pengabdian kepada masyarakat. Keluaran dari kegiatan penelitian dan pengabdian adalah Buku, Artikel, HKI, aplikasi dan lain-lain. Sesuai dengan peraturan Rektor Universitas Terbuka Nomor : 162 Tahun 2019 tentang perhargaan atas karya publikasi dan Hak Kekayaan Intelektual (HKI) di lingkungan Universitas Terbuka, dalam surat tersebut dijelaskan setiap dosen berhak mendapatkan penghargaan untuk setiap publikasi yang telah dilakukan, hanya saja saat ini proses pemberian penghargaan masih menggunakan cara manual, dosen mengisi form yang disediakan fakultas. Atas dasar proses yang lambat tersebut maka Tim peneliti menganggap Universitas Terbuka perlu mengembangkan sebuah aplikasi berbasis web, agar dapat menjadi sistem informasi bagi dosen untuk mengupdate proses pengusulan penghargaan atas karya publikasi dan Hak Kekayaan Intelektual (HKI) di lingkungan Universitas Terbuka. Penelitian menggunakan skema penugasan dan multi years selama dua tahun. Keluaran dari penelitian penugasan ini adalah artikel, HKI, dan prototipe aplikasi.

Keywords_- e-reward; sistem informasi manajemen; Aplikasi Website

\section{Pendahuluan}

Sumber daya manusia dalam hal ini adalah dosen merupakan aset penting suatu perguruan tinggi untuk mencapai tujuan di perguruan tinggi. Dosen adalah pendidik profesional dan ilmuwan dengan tugas utama mentransformasikan, mengembangkan, dan menyebarluaskan ilmu pengetahuan, teknologi, dan seni melalui pendidikan, penelitian, dan pengabdian kepada masyarakat menurut UU RI Nomor 14 Tahun 2005 tentang Guru dan Dosen. Jadi dari definisi dosen menurut UU RI di atas maka seorang dosen harus melakukan Tridharma perguruan tinggi yaitu Pendidikan, Penelitian dan Pengabdian Kepada Masyarakat [1].

Dosen saat ini diharapkan menjadi pakar dalam bidang kajian ilmunya dari proses penelitian kemudian disampaikan ke mahasiswa melalui pengajaran dan selain itu diberikan ke masyarakat melalui pengabdian kepada masyarakat. Saat ini dibeberapa perguruan tinggi contohnya Universitas Terbuka dari proses penelitian dan pengabdian diharapkan mendapatkan sebuah keluaran dalam bentuk Buku, artikel, Hak kekayaan intelektual (HKI), Naskah akademik, Aplikasi dan lain-lain [2]. 
Di Universitas Terbuka sesuai dengan peraturan Rektor Universitas Ter-buka Nomor: 162 Tahun 2019 tentang perhargaan atas karya publikasi dan Hak Kekayaan Intelektual (HKI) di lingkungan Universitas Terbuka, dalam surat tersebut dijelaskan setiap dosen berhak mendapatkan penghargaan untuk setiap publikasi yang telah dilakukan. Hanya saja saat ini proses pemberian penghargaan masih menggunakan cara manual dengan cara dosen mengisi form yang sudah ditentukan dan menyerahkanya kepada fakultas. Hal itu menjadi kendala karena dosen susah untuk mengetahui status dokumen apakah masih di fakultas atau sudah diajukan ke LPPM.

Berdasarkan latar belakang diatas, Tim peneliti menganggap Universitas Terbuka perlu mengembangkan sebuah aplikasi berbasis web untuk dapat menjadi sistem informasi bagi dosen untuk memperbaharui proses pengusulan penghargaan atas karya publikasi dan Hak Kekayaan Intelektual (HKI) di lingkungan Universitas Terbuka.

Penelitian yang akan dibangun bertujuan untuk membantu pihak Universitas Terbuka dalam memberikan layanan atau fasilitas jarak jauh kepada dosen yang berada baik di Pusat maupun Unit Program Belajar Jarak Jauh (UPBJJ), UPBJJ adalah unit pelaksana teknis UT di daerah, sehingga kegiatan pengusulan penghargaan untuk dosen atas karya publikasi dan Hak Kekayaan Intelektual (HKI) di lingkungan Universitas Terbuka dapat terpantau dengan baik. Tujuan lain yaitu membangun layanan jarak jauh dengan menggunakan system informasi berbasis Web.

\section{METODE PENELITIAN}

Kerangka berfikir dalam penelitian ini dapat dilihat pada Gambar 1, pertama melakukan pengumpulan data, selanjutnya data tersebut dilakukan analisis untuk mendapatkan desain informasi yang baik, setelah dianalisis mulai dilakukan coding untuk menjadikanya se-buah aplikasi. Setelah aplikasi jadi proses selanjutnya adalah implentasi dengan cara uji coba aplikasi dengan user terkait.

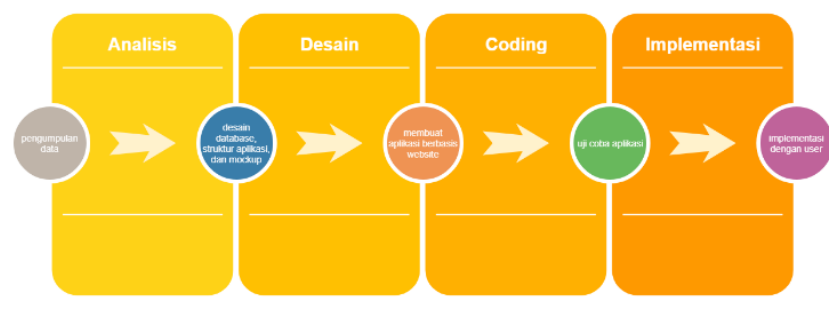

Gambar 1. Kerangka Berfikir Penelitian

Metode yang digunakan untuk membangun sistem informasi aplikasi pengusulan penghargaan atas publikasi dosen di penelitian ini yaitu menggunakan metode Waterfall. Menurut pressman (2015:42), metode waterfall adalah model sistematis dan berurutan dalam membagun perangkat lunak
[3]. Seperti terlihat pada Gambar 2. Terdapat 5 tahap yang harus dilalui dalam menggunakan metode ini yaitu: Analisis, Desain, Implementasi, Testing dan Pemeliharaan. Pada penelitian ini, kami menyadur metode waterfall tersebut hingga tahap ke-4, dikarenakan program yang dihasilkan hanyalah sebuah prototype, adapun maintenance kami lakukan pasca penelitian.

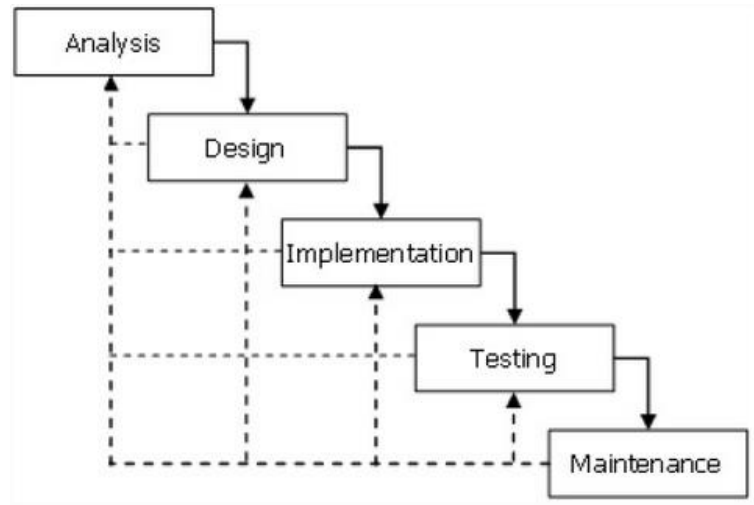

Gambar 2. Metode Waterfall

\section{A. Analisis}

Pada tahap analisis, kami akan menggali informasi melalui wawancara, observasi ke lapangan, serta studi litelatur. Berdasarkan penggalian informasi tersebut maka kami akan menganalisa berbagai kemungkinan baik dan buruknya pembangunan sistem informasi ini, sehingga kami akan menanggulanginya sesuai dengan kebutuhan dilapangan.

Secara detail hasil analisis yang kami dapatkan melalui wawancara, observasi dan studi literature adalah bahwa universitas belum mempunyai sebuah aplikasi untuk proses pengajuan reward, selain itu karena masih menggunakan cara manual yaitu menggunakan form, maka hal ini dapat mengakibatkan terjadinya kesalahan salah satu contoh kesalahan adalah form yang sudah diajukan tidak terproses. Biasanya tidak terproses akibat petugas kurang teliti untuk melakukan pengecekan pada form pengajuan yang sudah masuk.

Setelah mendapatkan analisis secara detail selanjutnya kami merekomendasikan yang akan dilakukan pada tahap implementasi nanti. Rekomendasi kami adalah aplikasi yang dibuat menggunakan perangkat lunak, perangkat keras, dan jaringan web hosting dan domain sesuai dengan kriteria berikut.

1. Perangkat lunak

a. Framework CodeIgniter

Dalam pengembangan apikasi ini, kami menggunakan Bahasa pemrograman PHP (Hypertext Preprocessor) dan memilih framework Codeigniter sebagai Framework untuk membuat aplikasi menggunakan Bahasa pemrograman PHP. 
Framework atau dalam bahasa indonesia dapat diartikan sebagai "kerangka kerja" merupakan kumpulan dari fungsi-fungsi/prosedur-prosedur dan class-class untuk tujuan tertentu yang sudah siap digunakan sehingga bisa lebih mempermudah dan mempercepat pekerjaan seorang programer, tanpa harus membuat fungsi atau class dari awal [4]

CodeIgniter juga memiliki dokumentasi yang super lengkap disertai dengan contoh implementasi kodenya. Dokumentasi yang lengkap inilah yang menjadi salah satu alasan kuat mengapa banyak orang memilih CodeIgniter sebagai framework pilihannya, walaupun menurut beberapa sumber framework ini masih kalah popular dibandingkan dengan framework Laravel [5]. Tapi Karena kelebihan-kelebihan yang dimiliki oleh CodeIgniter, banyak pengembang yang memilih framework ini, termasuk pembuat PHP Rasmus Lerdorf memuji CodeIgniter.

b. MySQL

MySQL adalah sebuah perangkat lunak sistem manajemen basis data SQL (database management system) atau DBMS yang multialur, multipengguna, dengan sekitar 6 juta instalasi di seluruh dunia. MySQL AB membuat MySQL tersedia sebagai perangkat lunak gratis di bawah lisensi GNU General Public License (GPL), tetapi mereka juga menjual di bawah lisensi komersial untuk kasus-kasus di mana penggunaannya tidak cocok dengan penggunaan GPL.

Tidak sama dengan proyek-proyek seperti Apache, di mana perangkat lunak dikembangkan oleh komunitas umum, dan hak cipta untuk kode sumber dimiliki oleh penulisnya masing-masing, MySQL dimiliki dan disponsori oleh sebuah perusahaan komersial Swedia MySQL AB, di mana memegang hak cipta hampir atas semua kode sumbernya. Kedua orang Swedia dan satu orang Finlandia yang mendirikan MySQL AB adalah: David Axmark, Allan Larsson, dan Michael "Monty" Widenius [6].

c. XAMPP

XAMPP adalah perangkat lunak bebas, yang mendukung banyak sistem operasi, merupakan kompilasi dari beberapa program. Fungsinya adalah se-bagai server yang berdiri sendiri (localhost), yang terdiri atas program Apache HTTP Server, MariaDB database, dan penerjemah bahasa yang ditulis dengan bahasa pemrograman PHP dan Perl. Nama XAMPP merupakan singkatan dari X (empat sistem operasi apapun), Apache, MariaDB, PHP dan Perl. Program ini tersedia dalam GNU General Public License dan bebas, merupakan web server yang mudah digunakan yang dapat melayani tampilan halaman web yang dinamis. Untuk mendapatkanya dapat mendownload langsung dari web resminya [7].

\section{Perangkat keras}
a. PC/ Laptop

b. Core i5

c. $\operatorname{Ram} 4 \mathrm{~Gb}$

d. HDD $500 \mathrm{G}$

Spesifikasi perangkat yang digunakan berdasarkan Minimum Recommended Requirements dalam mengembangkan perangkat lunak saat ini. Dan yang menjadi dasar menentukan spesifikasi perangkat keras adalah kami memilih standar dari merek PC/Laptop yang beredar saat ini. Dengan spesifikasi tersebut kami menganggap sudah cukup dalam proses pengembangan nantinya.

B. Testing

Testing dilakukan untuk mengetahui bug yang terdapat pada sistem, metode testing yang dapat digunakan yaitu metode Black box testing ataupun white box testing, untuk mengetahui kinerja dan kualitas dari sistem yang dibangun.

C. Desain

Desain yang dilakukan berasal dari informasi hasil analisis yang telah didapatkan, sehingga kami mampu mendesain sistem informasi atas karya publikasi dosen ini, secara garis besar pada tahapan desain ini terbagi menjadi beberapa bagian yaitu:

1. Rancangan konseptual Sistem

2. Rancangan Database

3. Rancangan Unified Modelling Language (UML)

4. Rancangan Struktur data

5. Rancangan pendekatan pengembangan perangkat lunak

6. Tampilan Sistem (Mockup)

\section{HASIL DAN PEMBAHASAN}

Setelah melakukan analisa sesuai dengan kebutuhan, proses analisa dilakukan dengan wawancara dan studi literature dan mendapatkan beberapa output diantaranya yaitu Rancangan struktur sistem, Rancangan database, dan Rancangan Mockup tampilan aplikasi. Semua hasil analisa dan pembahasan dapat dilihat pada berikut ini.

A. Analisis

Hasil analisis yang didapatkan adalah

1. Universitas Terbuka belum memiliki sebuah system dalam proses pengajuan reward untuk Publikasi dan HKI

2. Saat ini Universitas Terbuka masih melakukan cara manual yaitu dosen mengajukan form yang sudah disiapkan kepada petugas

3. Dalam setiap prosesnya sering terjadi masalah diantaranya adalah banyak Form yang diajukan tidak terproses

4. Karena rentan kesalahan sebaiknya Universitas Terbuka perlu membuat sebuah system dalam proses pengajuan reward publikasi dan HKI

B. Desain 
Hasil desain terdiri dari rancangan konseptual system, UML, ERD, dan rancangan mockup. Yang dapat dilihat pada pembahasan berikut ini.

1. Rancangan konseptual sistem

Setelah melakukan Analisis kebutuhan aplikasi, tahapan ini masih masuk di tahapan desain dalam metode waterfall yaitu membuat sebuah struktur sistem dengan rancangan sebagai berikut:

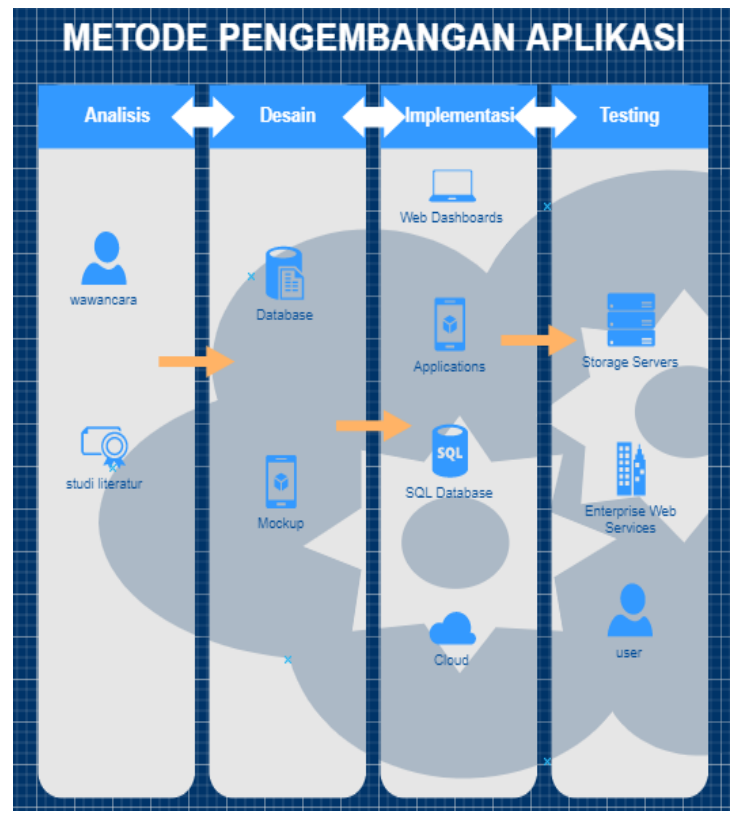

Gambar 3. Struktur sistem

Fungsi struktur ini adalah untuk memperjelas tahapan dalam pengembangan perangkat lunak.

\section{Rancangan mockup}

Setelah membuat rancangan struktur dan database, tahapan selanjutnya adalah membuat rancangan halaman user interface dalam bentuk mockup, dengan detail halaman berikut ini

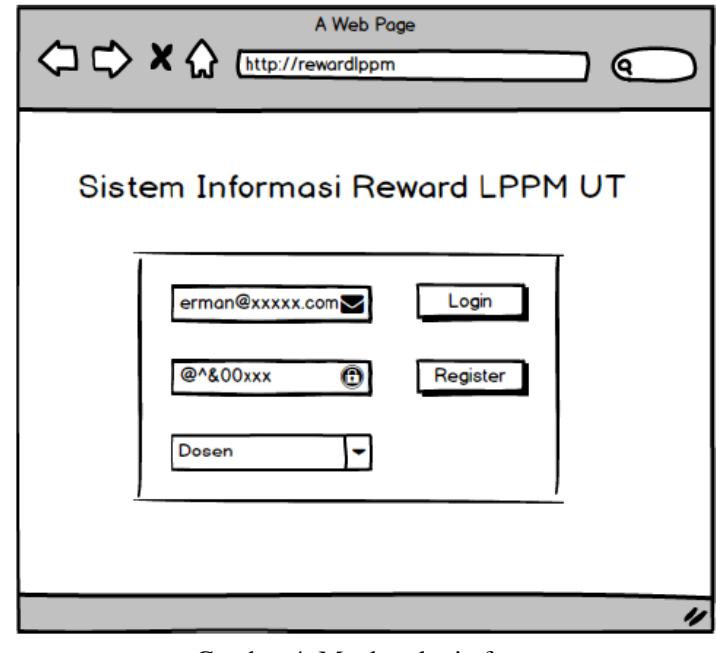

Gambar 4. Mockup login form
Pada mockup login form terdapat dua button yaitu login dan register. Selain button pada rancangan mockup ini juga menambahkan dua Text field dan satu drop down untuk memilih tipe pengguna

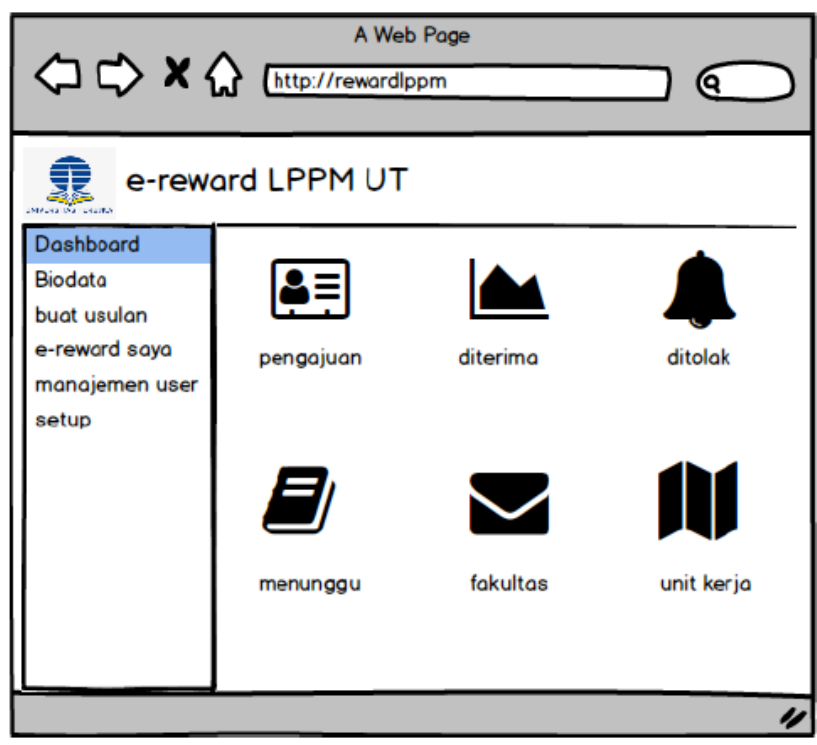

Gambar 5. Mockup Dashboard

Pada rancangan halaman dashboard menggunakan tiga frame yang terdir dari floating menu samping dan beberapa shortcut informasi pada content.

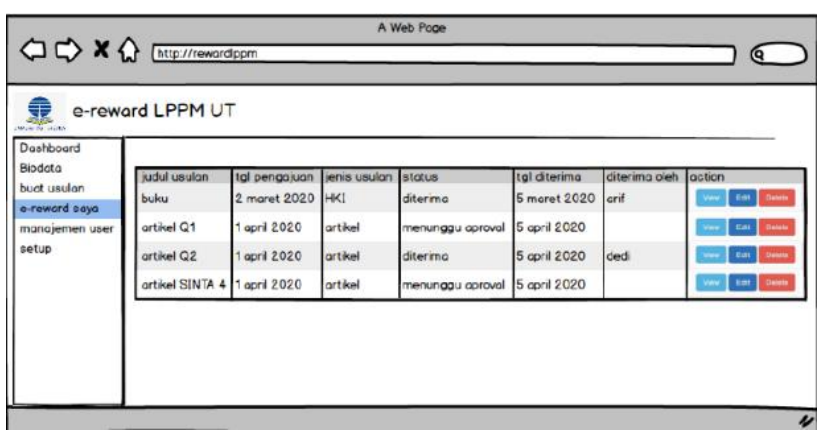

Gambar 6. Mockup e-reward saya

Rancangan halaman e-reward saya menggunakan tampilan grid menu yang dalamnya terdapat tiga button yaitu edit, delete, dan view.

Fungsi dari masing-masing button disesuaikan dengan kebutuhan user contoh button edit digunakan untuk merubah data, delete digunakan untuk menghapus data, dan view digunakan untuk melihat data. Pada dasarnya halaman ini dirancangan untuk memudahkan user dalam proses pengajuan reward untuk publikasi dan HKI. 
3. Rancangan Unified Modelling Language (UML)

Unified Modeling Language (UML) adalah sebuah bahasa yang berdasarkan grafik atau gambar untuk memvisualisasi, menspesifikasikan, membangun, dan pendokumentasian dari sebuah sistem pengembangan software berbasis OO (Object-Oriented). Pengertian dari $\mathrm{OO}$ (Object Oriented) adalah sebuah istilah yang diberikan kepada bahasa pemrograman yang menggunakan tehnik berorientasi atau berbasis pada sebuah obyek dalam pembangunan program aplikasi [8].

UML sendiri juga memberikan standar penulisan sebuah sistem blue print, yang meliputi konsep bisnis proses, penulisan kelas-kelas dalam bahasa program yang spesifik, skema database, dan komponen-komponen yang diperlukan dalam sistem software[9]

a. Use Case Diagram

Aktor yang bertanggung jawab dalam use case diagram yaitu administrator, dosen dan admin fakultas. Masing-masing aktor menjalankan tugas sesuai hak akses terhadap sistem. Rancangan Diagram Usecase bisa dilihat pada gambar berikut ini.

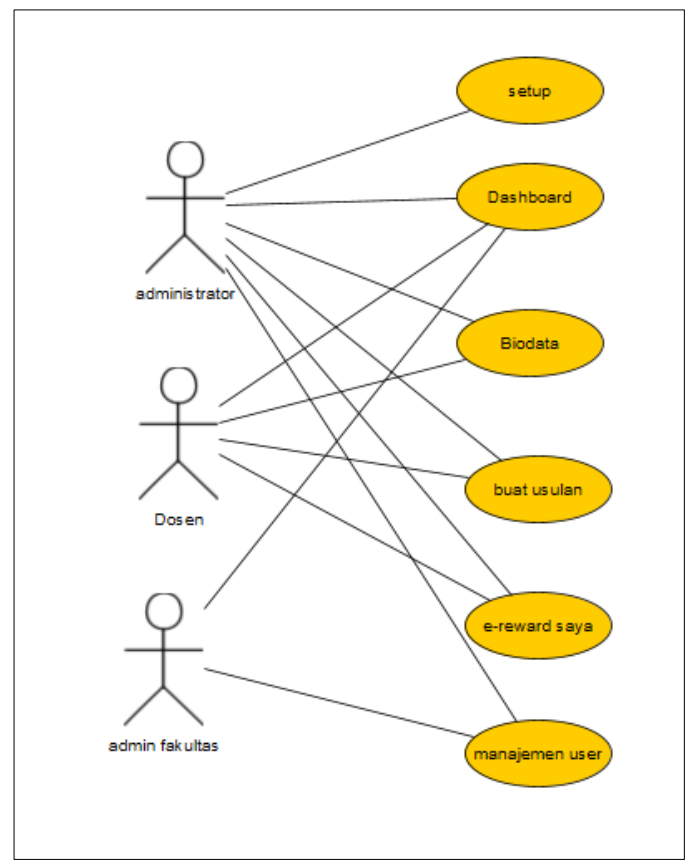

Gambar 7. Use case diagram

\section{b. Activity Diagram}

Diagram Activity merupakan gambar aktivitas user terhadap semua menu yang dibuat dalam sistem, Rancangan Diagram activity bisa dilihat pada gambar berikut ini

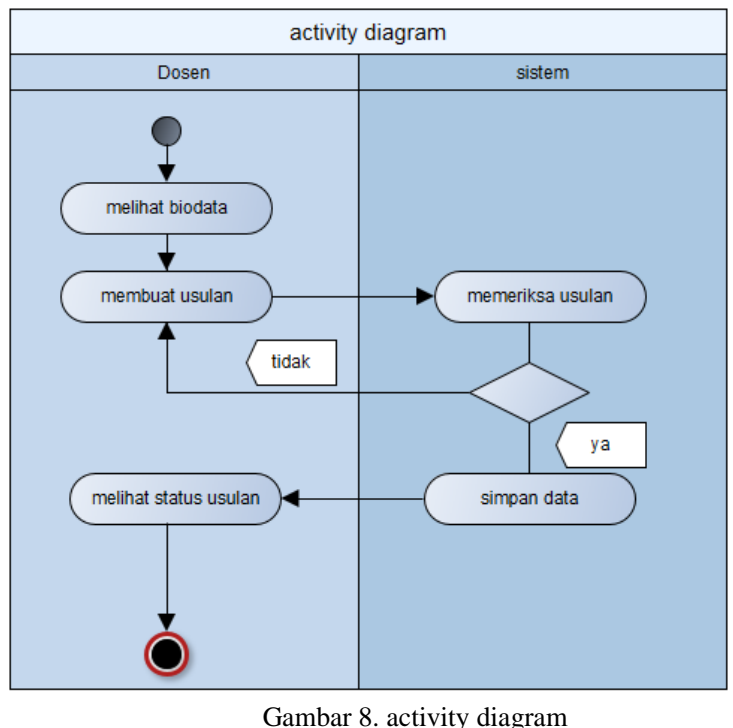

c. Sequence Diagram

Diagram Sequence merupakan gambar kegiatan user berdasarkan rangkaian urutan waktu penggunaan sistem. Rancangan diagram sequence bisa dilihat pada gambar berikut ini.

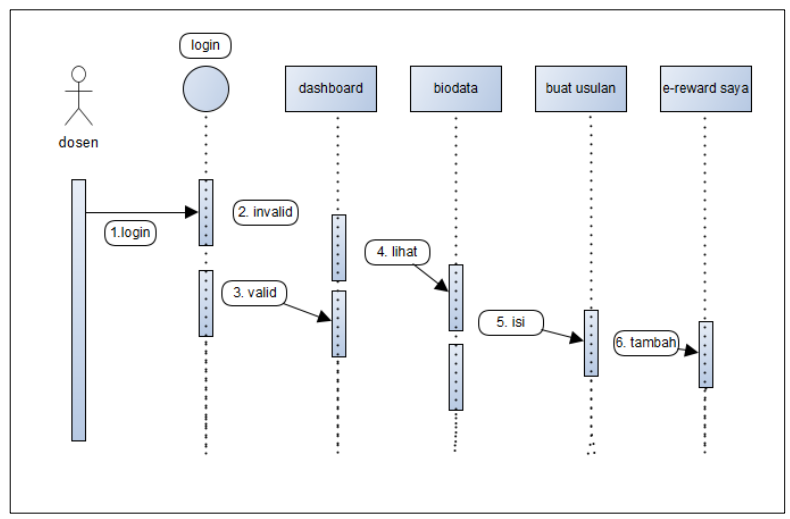

Gambar 9. Sequence diagram

4. Rancangan Entity Relationship Diagram (ERD)

entity Relationship Diagram (Diagram E-R) adalah yang digunakan untuk menggambarkan model Entity Relationship yang berisi komponen-komponen. Himpunan Entitas dan Himpunan Relasi yang masing-masing dilengkapi dengan atribut-atribut yang mempersentasikan seluruh fakta dari dunia nyata yang kita tinjau [10]. Berikut adalah rancangan ERD pada aplikasi.

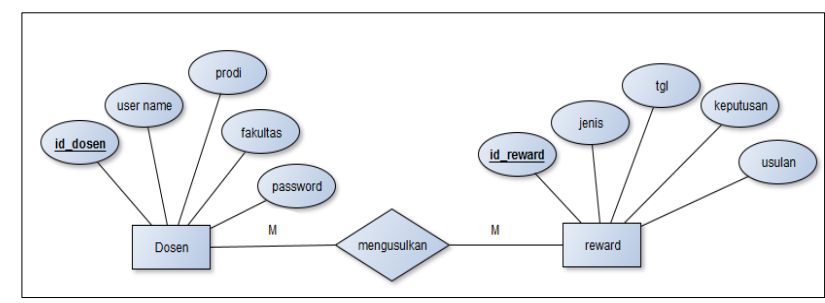

Gambar 10. Rancangan ERD 
Keterangan:

Gambar diatas menjelaskan alur pengajuan usulan reward dosen. Yang terdiri atas 2 (dua) entitas yaitu Dosen dan Reward, 1 (satu) relasi yaitu mengusulkan, dan berbagai atribut. Sedangkan untuk kardinalitas rasio menggunakan rasio Many to many (M:M) yang berarti setiap entitas dapat berhubungan dengan banyak entitas lainya begitupun juga sebaliknya. Secara proses dapat diuraikan seperti berikut misal pada saat seorang dosen akan mengajukan pengusulan reward, dicatatlah id dosen, user name, prodi dan Fakultas. Setelah itu dosen baru bisa mengusulkan pengajuan reward, lalu setelah itu akan dicatat pada entitas reward dengan atribut yang sudah ditentukan yaitu id reward, jenis, tgl, keputusan dan usulan.

\section{Kesesuaian hasil perancangan dan kebutuhan}

Berdasarkan hasil analis dan desain yang sudah dibuat maka dapat kami asumsikan bahwa hasil perancangan yang sudah dibuat seperti rancangan konseptual system, Rancangan Database, rancangan struktur data, Rancangan pengembangan perangkat lunak, dan rancangan mockup. Dapat memenuhi kebutuhan user dalam hal ini adalah Universitas Terbuka untuk kegiatan pengajuan reward atas publikasi dan HKI di lingkungan Universitas Terbuka.

Kesusuaian hasil perancangan dapat terlihat dari bagaimana setiap desain dapat menampung semua kebutuhan yang Universitas Terbuka perlukan. Maka dapat disimpulkan bahwa hasil rancangan sudah sesuai dengan kebutuhan Universitas Terbuka.

Hal ini juga dapat tergambar pada umpan balik kuesioner yang kami berikan kepada responden.

\begin{tabular}{|ll|}
\hline More Detals & \\
1 & 0 \\
2 & 0 \\
3 & 1 \\
4 & 16 \\
5 & 5 \\
\hline
\end{tabular}

Gambar 11. Umpan balik kuesioner

Terdapat 16 responden memberikan nilai 4 (baik) dengan persentase $73 \%$, kemudian 5 peserta memberikan nilai 5 (sangat baik) dengan persentase $23 \%$. Berikutnya terdapat 1 responden memberikan nilai 3 (biasa) dengan persentase $5 \%$.

\section{KESIMPULAN}

Berdasarakan hasil penelitian yang sudah dilakukan, dapat diambil beberapa kesimpulan. Kesimpulan tersebut dapat dipaparkan sebagai berikut.

1. Pembuatan desain mockup, desain database, dan desain struktur system aplikasi pengajuan reward untuk publikasi ilmiah dan HKI sangat membantu untuk tahapan waterfall berikutnya yaitu Implentasi. Karena hasil desain ini dapat memudahkan pengembangan aplikasi dalam tahapan coding.

2. Hasil kesesuaian rancangan dan kebutuhan sudah $100 \%$ sesuai kebutuhan Universitas Terbuka.

3. Metode Waterfall dapat memudahkan peneliti untuk menyelesaikan penelitian. bisa disimpulkan $100 \%$ sangat membantu.

\section{UCAPAN TERIMA KASIH}

Akhirnya, kami ingin mengucap-kan terima kasih kepada keluarga kami dan semua pihak atas dukungan selama ini.

\section{DAFTAR PUSTAKA}

[1] R. V. Imbar, "Pengembangan Konsep Kompensasi Dosen dengan mekanisme reward/punishment ditopang dengan konsep sustainabilitas keuangan dengan menggunakan Sistem Informasi. (Studi Kasus : Universitas X)," J. Tek. Inform. dan Sist. Inf., vol. 5, no. 2, pp. 212-220, 2019.

[2] LPPMP, Katalog Sistem Penyelenggaraan Universitas Terbuka 2019/2020, 1st ed. INDONESIA, 2019.

[3] F. Darnis, "WEBSITE CV CAHAYA MOTOR SEBAGAI," no. 2015, pp. 8-9, 2018.

[4] Icloudhost, "Mengenal Apa itu Framework CodeIgniter," 2017. [Online]. Available: https://idcloudhost.com/panduan/mengenal-apaitu-framework-codeigniter/.

[5] Guntoro, "10 Framework PHP yang Paling Populer di Tahun 2020," 2020. [Online]. Available: https://badoystudio.com/framework-php/.

[6] M. Destiningrum and Q. J. Adrian, "SISTEM INFORMASI PENJADWALAN DOKTER BERBASSIS WEB DENGAN MENGGUNAKAN FRAMEWORK CODEIGNITER ( STUDI KASUS : RUMAH SAKIT YUKUM MEDICAL CENTRE ),” vol. 11, no. 2, pp. 30-37, 2017.

[7] F. Ayu, "PERANCANGAN SISTEM INFORMASI PENGOLAHAN DATA PRAKTEK KERJA LAPANGAN (PKL) PADA DEVISI HUMAS PT. PEGADAIAN," vol. 2, no. 2, pp. 12-26, 2018.

[8] M. Danuri, "OBJECT ORIENTED PROGRAMMING ( OOP ) PEMBANGUN PROGRAM APLIKASI,” pp. 40-47.

[9] Suendri, "Implementasi Diagram UML (Unified Modelling Language) Pada Perancangan Sistem Informasi Remunerasi Dosen Dengan Database Oracle (Studi Kasus: UIN Sumatera Utara Medan)," vol. 6341, no. November, pp. 1-9, 2018.

[10] Andri Sukmaindrayana, "APLIKASI GROSIR PADA TOKO RSIDIK BUNGURSARI TASIKMALAYA,” vol. 4, no. 2, 2017. 